\title{
Als het functioneren tekortschiet
}

Jan-Willem Weenink

\author{
Huisartsen zijn oververtegenwoordigd in tuchtzaken. Het \\ wordt ook steeds belangrijker dat je kunt aantonen dat je je \\ vak op een verantwoorde manier uitoefent, maar huisartsen \\ maken vaak onvoldoende gebruik van de bestaande moge- \\ lijkheden om te reflecteren op hun eigen functioneren en op \\ dat van collega's.
}

Huisartsen moeten steeds vaker kunnen aantonen dat ze voldoen aan normen en standaarden en dat ze hun vak op een verantwoorde manier uitoefenen. Dat gaat de meesten goed af, maar niet iedereen. De afgelopen jaren is onderzocht hoe Nederlandse zorgverleners, waaronder huisartsen, omgaan met verminderd functioneren van henzelf of van collegas. En hoe huisartsen het doen in vergelijking met andere BIG-geregistreerde beroepsgroepen en met buitenlandse collega's.

\section{VERANTWOORD FUNCTIONEREN}

Om verantwoord te kunnen functioneren moet men weten wat daaronder verstaan wordt. ${ }^{1}$ Daartoe dienen kwaliteitskaders en gedragsregels. De KNMG heeft deze beschreven in het Kwaliteitskader medische zorg (2012), en daarin ook aangegeven wat er van artsen verwacht mag worden op het gebied van kwaliteitsbevordering en verantwoording. De Federatie Medisch Specialisten heeft in het visiedocument Optimaal functioneren (2013) uitgangspunten vastgelegd voor het continu verbeteren van het eigen functioneren. Voor huisartsen is er op dit moment geen vergelijkbaar document. Beroepsgroepen zoals tandartsen en verloskundigen kennen kwaliteitsregisters van beroepsbeoefenaars. Het

\section{DE KERN}

- Minder dan de helft van de huisartsen gebruikt de beschikbare instrumenten om het eigen functioneren te evalueren.

- Huisartsen ervaren onvoldoende ondersteuning in het omgaan met collega's die minder goed functioneren.

- Er zou aandacht moeten zijn voor emotionele ondersteuning tijdens en na een tuchtzaak. Op lokaal niveau zijn zulke initiatieven er al.

- Er is al een steunpunt voor artsen met een verslaving; een steunpunt voor functioneringsproblemen in bredere zin zou wenselijk zijn.

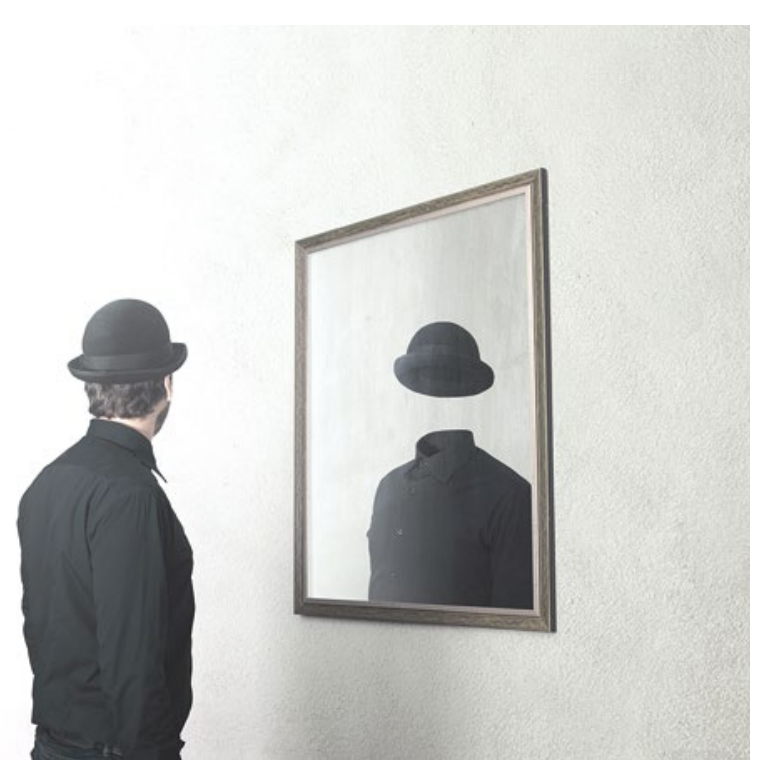

Huisartsen weten niet altijd hoe om te gaan met een collega die disfunctioneert

Foto: iStock

doel hiervan is dat de zorgverlener kan laten zien dat hij/zij niet alleen bevoegd maar ook bekwaam is om het beroep uit te oefenen.

\section{INZICHT IN HET EIGEN FUNCTIONEREN}

Om verantwoord te kunnen functioneren is het van belang inzicht te hebben in het eigen functioneren. ${ }^{2}$ Bij zorgverleners die minder goed functioneren, ontbreekt dat inzicht vaak. Sommigen onttrekken zich ook aan hun professionele omgeving en gaan bijvoorbeeld feedback van collega's uit de weg. ${ }^{3}$ Huisartsen hebben de mogelijkheid om met collega's te reflecteren op het eigen functioneren, tijdens de opleiding zijn er bijvoorbeeld terugkomdagen en daarna zijn er intervisiebijeenkomsten. Maar lang niet alle huisartsen lijken zich bewust te zijn van het belang daarvan. Toen wij dit in 2013 en 2015 onderzochten, bleek nog geen 50\% van de huisartsen daadwerkelijk methodes of instrumenten te gebruiken om het eigen functioneren te evalueren. ${ }^{4}$ Ter vergelijking: het gemiddelde voor alle BIG-geregistreerde beroepsgroepen lag tussen de 60 en $65 \%$. Nu visitatie verplicht is om voor herregistratie in aanmerking te komen (brief van 5 oktober 2016 van de RGS), zal dit percentage ook onder huisartsen toenemen. Belangrijk is wel dat ze de feedback op hun functioneren ook daadwerkelijk gebruiken voor reflectie en professionele ontwikkeling. 


\section{DE COLLEGA DIE VERMINDERD FUNCTIONEERT}

Collega's hebben een belangrijke rol bij het tijdig signaleren en bespreekmaar maken van verminderd functioneren. Dat is niet eenvoudig. In ons onderzoek gaf ongeveer twee derde van de huisartsen aan dat ze wisten hoe te handelen bij vermeend disfunctioneren van een collega-huisarts in de eigen praktijk. Als het een collega buiten de eigen praktijk betrof, was dat een stuk minder: ongeveer een derde. Van degenen die daadwerkelijk te maken hadden gehad met een disfunctionerende collega, had ongeveer twee derde actie ondernomen, vooral door hun vermoeden te bespreken met die collega of met

\section{Een steunpunt voor functioneringsproblemen kan toegevoegde waarde hebben}

andere collega's. De huisartsen die geen actie hadden ondernomen, gaven als belangrijkste reden dat het disfunctioneren niet bewezen kon worden. ${ }^{4}$

De LHV ondersteunt huisartsen met onder andere een modelprotocol [kader 1], maar niet alle huisartsen zijn daarmee bekend of gebruiken het. Van de huisartsen die wij ondervroegen, gaf slechts een derde aan dat ze steun vonden bij een protocol van de beroepsgroep en meldde iets meer dan de helft dat ze ondersteuning kregen vanuit de eigen praktijk. Ze gaven wel aan dat er in de opleiding meer aandacht voor dit soort situaties zou moeten zijn en dat ze behoefte hadden aan een plek om vermeend disfunctioneren te kunnen melden, zoals bijvoorbeeld apothekers die hebben. ${ }^{4}$

\section{DE IMPACT VAN EEN TUCHTZAAK}

In vergelijking met andere BIG-geregistreerde zorgverleners zijn artsen in het algemeen, maar huisartsen in het bijzonder, oververtegenwoordigd in tuchtzaken. In 2016 betrof ongeveer een vijfde van alle afgehandelde klachten de huisartsgeneeskunde. ${ }^{5}$ Als een klacht gegrond wordt bevonden, krijgt de angeklaagde in beginsel een maatregel opgelegd. Het tuchtrecht heeft als doel de kwaliteit van de beroepsbeoefening te bevorderen en te bewaken. Dat werkt op het niveau van de beroepsgroep, door het bewustzijn over normen te vergroten, en op het niveau van de aangeklaagde zorgverlener, door een correctieve maatregel. Of een tuchtzaak dat laatste doel ook altijd bereikt, is maar de vraag. Zorgverleners zeiden dat ze na een maatregel defensiever te werk gingen uit angst voor toekomstige klachten. $\mathrm{Zij}$ meden bijvoorbeeld risicovolle patiënten of vroegen uit voorzichtigheid vaker aanvullend onderzoek aan. Slechts een op de zes zorgverleners gaf aan zich te kunnen vinden in de maatregel. ${ }^{6}$

Een tuchtzaak kan ook een behoorlijke persoonlijke impact hebben: zorgverleners rapporteerden gevoelens van ellende en onzekerheid tijdens en na de tuchtzaak. ${ }^{7}$ De vaak lange duur van het tuchtproces draagt daaraan bij. In het Verenigd
Koninkrijk biedt de beroepsvereniging steun aan artsen van wie het functioneren onderzocht wordt en ook in Noorwegen kunnen artsen in tijden van spanning emotionele ondersteuning krijgen vanuit de beroepsvereniging. Nederland kent zulke ondersteuning niet op landelijk niveau, maar wel zijn er sinds enkele jaren lokale initiatieven om huisartsen bij traumatische gebeurtenissen - waaronder tuchtklachten peer-support te geven [kader 2].

\section{HERSTEL BIJ EEN FUNCTIONERINGSPROBLEEM}

Landelijk is er in Nederland nog weinig aandacht voor zorgverleners met een functioneringsprobleem. ABS-artsen (project KNMG) geeft vertrouwelijke hulp aan artsen die kampen met problematisch middelengebruik [kader 3]. Soortgelijke hulpprogramma's in het buitenland lijken positieve effecten te hebben, maar in Nederland zijn ze nog niet onderzocht. Of zulke steun ook bij andere cognitieve of fysieke problemen effect sorteert, is niet zeker, maar er is wel behoefte aan. ${ }^{9,10} \mathrm{Er}$ zijn in ons land gespecialiseerde instellingen die bredere tweedelijns psychotherapeutische zorg bieden aan zorgprofessionals, maar ze zijn klein en niet makkelijk te vinden. Er zijn dus wel voorbeelden te vinden van instellingen die steun bieden bij specifieke problemen in het functioneren, maar functioneringsproblemen zijn vaak het gevolg van een samenstel van factoren. Je kunt je afvragen of er niet een steunpunt voor huisartsen zou moeten komen met een bredere focus, zoals de Monitor Mondzorg in brede zin tandartsen steunt die in de problemen komen, onafhankelijk van wat eraan ten grondslag

KADER 1: ONDERSTEUNING VANUIT DE LHV

De LHV geeft op diverse manieren ondersteuning aan het functioneren van de huisarts.

- In de cursus De [zichzelf] coachende huisarts, waarin de cursist reflecteert op het eigen functioneren en leert het zelfoplossend vermogen van patiënten, medewerkers en collega's aan te spreken.

- De LHV ontwikkelde in samenwerking met het NHG het Visitatieprogramma Huisartsen. Vanaf 2020 is visitatie verplicht voor herregistratie.

- Huisartsen die problemen ervaren met hun eigen functioneren dan wel aangesproken zijn op hun functioneren of huisartsen die problemen ervaren met het functioneren van collega's kunnen terecht bij een vertrouwenspersoon van de LHV.

- De praktijkkaart Hulp bij vermoeden van disfunctioneren biedt handvatten voor een adequate reactie op een vermoeden van verminderd functioneren.

- Het Modelprotocol vermeend disfunctioneren huisarts beschrijft de te volgen procedure bij een vermoeden van disfunctioneren.

- LHV en InEen hebben een Landelijke Commissie van Advies opgericht die huisartsen ondersteunt bij procedures inzake disfunctioneren. ${ }^{1,4}$ 


\section{KADER 2: HET BOT-BUDDYTEAM}

De Trauma Nazorg Groep, een landelijke organisatie die voor bedrijven en instellingen zogeheten bedrijfsopvangteams [BOT] opzet, startte enkele jaren geleden het BOT-buddyteam op huisartsenposten in NoordBrabant. In dit team zitten huisartsen en verpleegkundigen die extra begeleiding kunnen geven na ernstige incidenten tijdens een dienst op de hap en ook bij de klachten- of tuchrechtprocedure die daar soms op volgt. Een van de teamleden, een gepensioneerd huisarts, vertelt over zijn ervaringen.

'Ik heb zelf twee huisartsen begeleid bij een tuchtzaak. Eén huisarts had een goed vangnet waarvan hij veel steun kreeg, maar toch vond hij het zelf onverwacht prettig dat ik hem vergezelde naar de zitting van het tuchtcollege. Op zo'n moment ben je toch een ruggensteun voor iemand. Er is niet altijd intensieve hulp nodig, maar het is goed als iemand kan signaleren of de situatie niet ontspoort. Maar ik heb ook een paar keer meegemaakt dat alle hulp werd afgehouden. Dat zit diepgeworteld in artsen: dat je aan de ene kant als arts geen fouten mag maken, maar óók dat je geen hulp zoekt. Hulp accepteren voelt als een soort zwaktebod.' Overgenomen uit Paauw $2017^{8}$

ligt of hoe ze tot uiting komen. Tandartsen kunnen zichzelf bij de monitor melden, maar ook collega's of patiënten kunnen er hun zorgen kwijt over het functioneren van een tandarts.

\section{CONCLUSIE}

Vanuit de beroepsgroep lijkt er voldoende gelegenheid te zijn om te reflecteren op het eigen functioneren. Huisartsen weten echter niet altijd waar ze naartoe kunnen met een signaal van vermeend disfunctioneren en zijn niet altijd op de hoogte van de bestaande protocollen. In de opleiding zou meer aan de orde kunnen komen hoe om te gaan met een collega die mogelijk disfunctioneert. Daarnaast is er behoefte aan een plek om zulke signalen te melden en zou er meer aandacht moeten komen voor ondersteuning bij tuchtklachten. Er zijn al lokale initiatieven; de vraag is of dit ook landelijk moet worden opgepakt. Een belangrijk laatste punt is ondersteuning bij mogelijke functioneringsproblemen: het is in ieders belang dat die tijdig worden aangepakt. Nederland heeft al een landelijk steunpunt voor verslaafde artsen; een steunpunt voor bredere functioneringsproblemen, zoals dat al bestaat voor tandartsen, zou toegevoegde waarde kunnen hebben.

\section{LITERATUUR}

1. Weenink JW, Kool RB, Hesselink G, Bartels RH, Westert GP. Prevention of and dealing with poor performance: an interview study about how professional associations aim to support healthcare professionals. Int J Qual Health Care 2017;29:838-44.

\section{KADER 3: DE VERSLAAFDE HUISARTS}

Een huisarts had zoveel last van de stijgende werkdruk dat ze zich buiten werktijd begon te verdoven met medicijnen. Wie wil weten hoe de verslaving begon, zou kunnen beginnen bij het moment dat een ex-gedetineerde patiënt haar vastgreep in zijn flat op de vierde etage en zei dat hij haar uit het raam zou gooien. Of bij de doodsbedreigingen door patiënten die hun zin niet kregen. Of bij het feit dat ze's avonds om half twaalf thuiskwam, stijf van de adrenaline nadat ze om elf uur nog iemand had staan reanimeren, en merkte dat ze niet meer kon ontspannen. Pillen werden haar ontspanning: temazepam. Eerst af en toe, maar gaandeweg in hogere doseringen. Later nam ze haar toevlucht tot morfine. Ze wist haar verslaving verborgen te houden voor haar man en kinderen. Het viel hun wel op dat ze zo afwezig oogde, maar dat kwam waarschijnlijk omdat ze het erg druk had, dachten ze. Haar apotheker rook echter onraad en confronteerde haar ermee dat ze veel meer medicatie voorschreef dan andere huisartsen. Een collega deed vervolgens melding bij de Inspectie voor de Gezondheidszorg. Sindsdien heeft ze niet meer als huisarts gewerkt. Ze gaat nu meedoen aan het vijfjarenplan van de KNMG voor [ex-]verslaafde dokters. Daarin staan artsen vijf jaar onder controle van een bedrijfsarts en worden ze regelmatig getest op middelengebruik. 'Mijn grootste angst is dat ik niet meer terug aan de slag mag als huisarts', zegt ze.

Overgenomen uit Witteman 2016. ${ }^{11}$

2. Brown N, McAvoy P, Joffe M. Defining insight: a challenge that matters. Clin Teach 2014;11:170-3.

3. Holden JD, Cox SJ, Hargreaves S. Avoiding isolation and gaining insight. BMJ Careers, 16 Feb 2012.

4. Weenink JW, Kool RB. Sturen op functioneren en omgaan met verminderd functioneren van zorgverleners. Nijmegen: IQ healthcare, 2016.

5. Gezamenlijk jaarverslag Tuchtcolleges voor de Gezondheidszorg en College van Medisch Toezicht 2016. Den Haag: Tuchtcolleges voor de Gezondheidszorg, 2017.

6. Friele R, Hendriks M, Laarman B, Bouwman R, De Veer A. Zorgverleners en burgers over het openbaar maken van door de tuchtrechter opgelegde berispingen en geldboetes. Utrecht: NIVEL, 2017.

7. Verhoef LM, Weenink JW, Winters S, Robben PB, Westert GP, Kool RB. The disciplined healthcare professional: a qualitative interview study on the impact of the disciplinary process and imposed measures in the Netherlands. BMJ Open 2015;5:e009275.

8. Paauw S. Een collega als buddy. Medisch Contact, 1 april 2015.

9. Weenink JW, Kool RB, Bartels RH, Westert GP. Getting back on track: a systematic review of the outcomes of remediation and rehabilitation programmes for healthcare professionals with performance concerns. BMJ Qual Saf 2017;26:1004-14.

10. Paauw S. 'Ik zag de volle spreekkamer en raakte in paniek': Unieke ggz-instelling helpt artsen met psychische problemen. Medisch Contact, 21 augustus 2017.

11. Witteman J. Snoepen uit de dokterstrommel: verslavingen onder huisartsen. de Volkskrant, 21 april 2016. 
Weenink JW. Als het functioneren tekortschiet. Huisarts Wet 2018;61:DOI: 10.1007/s12445-018-0231-z.

Erasmus School of Health Policy \& Management, Rotterdam: dr. J.W. Weenink, universitair docent, weenink@eshpm.eur.nl. Mogelijke belangenverstrengeling: niets aangegeven.

Jan-Willem Weenink is op maandag 16 april 2018 gepromoveerd aan de Radboud Universiteit Nijmegen op het proefschrift Back on track: addressing poor performance of healthcare professionals. 